\title{
Isolation and characterization of a $n t r C$ mutant of Bradyrhizobium (Parasponia) sp. ANU289
}

\author{
Michael K. Udvardi, ${ }^{*}$ Diane L. Lister and David A. Day \\ Division of Biochemistry and Molecular Biology, Australian National University, GPO Box 4, Canberra ACT 2601, Australia
}

(Received 29 October 1991; accepted 22 January 1992)

\begin{abstract}
A mutant of Bradyrhizobium (Parasponia) sp. ANU289 affected in the regulation of nitrogen metabolism was isolated. The mutant, designated ANU293, was unable to induce ammonium transport (Amt), nitrate reductase (NR) or glutamine synthetase II (GSII) activities under conditions that induce these activities in the wild-type. However, glutamine synthetase I (GSI), which is expressed constitutively in the wild-type, was present at normal levels in the mutant. The mutant also retained the ability to fix nitrogen in vitro and in planta, although nodule development on siratro (Macroptilium atropurpureum) was retarded. Southem blot analysis showed that ntr $C$, the product of which is involved in regulation of nitrogen metabolism, is the site of pSUP1021 insertion in ANU293. These results indicate that the transcriptional activator NtrC is required for the expression of Amt, NR and GSII, but not GSI or nitrogenase in Bradyrhizobium (Parasponia) sp. ANU289.
\end{abstract}

\section{Introduction}

In enteric bacteria such as Escherichia coli and Klebsiella pneumoniae, several nitrogen assimilation pathways are coordinately regulated by a central nitrogen regulation (Ntr) system (Magasanik, 1982). Three genes, $n$ tr $A$, ntrB and $n t r C$, are responsible for overall nitrogen regulation in these bacteria. Genes under Ntr control include $g \ln A$, encoding glutamine synthetase (GS), and several others involved in the utilization of amino acids such as L-arginine, L-proline and L-histidine (Magasanik, 1982). Also under Ntr control is the gene(s) encoding ammonium ( $\mathrm{NH}_{4}^{+}$) transport (amt; Servin-Gonzalez \& Bastarrachea, 1984; Jayakumar et al., 1986). In $K$. pneumoniae, the nitrogen fixation (nif) genes are also controlled by the Ntr system (Ausubel, 1984; Gussin et al., 1986).

A Ntr system has also been shown to operate in species of Rhizobiaceae. Homologues of $n \operatorname{tr} A, n \operatorname{tr} B$ and $n \operatorname{tr} C$ have been identified in members of the Rhizobiaceae, and both $n t r A$ and $n t r C$ have been shown to be necessary for expression of several genes involved in nitrogen assimi-

\footnotetext{
* Author for correspondence. Present address: CSIRO, Division of Plant Industry, Canberra ACT 2601, Australia.

Abbreviations: Amt, ammonium transport; GSI, glutamine synthetase I; GSII, glutamine synthetase II; NR, nitrate reductase; Ntr, nitrogen regulation.
}

lation (Ausubel et al., 1985; Nixon et al., 1986; Pawlowski et al., 1987; Ronson et al., 1987; Rossbach et al., 1987; Szeto et al., 1987; Martin et al., 1988; Shatters et al., 1989; Stanley et al., 1989). However, it has become apparent from these studies that the pattern of $\mathrm{Ntr}$ control in Rhizobiaceae differs from that found in the enteric bacteria. For example, whilst $g \ln A$ is under the control of the Ntr system in enteric bacteria (Magasanik, 1982), its homologue in Azorhizobium and Bradyrhizobium species is not (Pawlowski et al., 1987; Carlson et al., 1987). A second, eukaryote-like glutamine synthetase (GSII, encoded by $g \ln I I$ ) that is present in (brady)rhizobia is, on the other hand, regulated by the Ntr system (Carlson et al., 1987; Martin et al., 1988; Shatters et al., 1989). Whilst transcription of the nitrogen fixation (nif) genes is absolutely dependent on the activator $\mathrm{NtrC}$ in the free-living bacterium Klebsiella pneumoniae, this is not the case in Rhizobium meliloti and Azorhizobium caulinodans, at least during symbiotic nitrogen fixation (Gussin et al., 1986; Szeto et al., 1987; Pawlowski et al., 1987). Furthermore, NtrC is not necessary for the utilization of amino acids in Rhizobiaceae (Szeto et al., 1987; Pawlowski et al., 1987; Martin et al., 1988).

Although differences in the pattern of Ntr control in Rhizobiaceae and enteric bacteria have been identified, the extent of $\mathrm{Ntr}$ control in the former remains unknown. In this paper we describe the isolation and characterization of a $n t r C$ mutant of Bradyrhizobium (Parasponia) sp. ANU289. The mutant is affected in the regulation of not 
only glutamine synthetase II (GSII) and nitrate reductase (NR), but also $\mathrm{NH}_{4}^{+}$transport (Amt). Growth of the mutant on a variety of nitrogen sources and its nitrogen-fixing ability, both in vitro and in planta, were also studied.

\section{Methods}

Bacterial strains. Bradyrhizobium (Parasponia) sp. ANU289 is a streptomycin-resistant, non-mucoid derivative of strain CP283 (Trinick \& Galbraith, 1980). It can form effective nodules on some tropical legumes, as well as on the tropical non-legume Parasponia. The Tn 5 mutant bank of strain ANU289 was generously provided by $\mathrm{Dr}$ Susan Howitt (see Howitt et al., 1988, for details). The mutant isolated from this bank and described herein is designated strain ANU293.

Media and growth conditions. The basic (nitrogen-free) liquid growth medium was N-FGM (Howitt \& Gresshoff, 1985), with nitrogen sources supplied at a concentration of $10 \mathrm{mM}$ unless otherwise stated. Cultures $(100 \mathrm{ml})$ were grown aerobically at $30^{\circ} \mathrm{C}$ by shaking in $250 \mathrm{ml}$ side-arm flasks at 200 r.p.m. The following solid media (containing

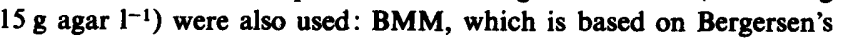
medium (Bergersen, 1969), except that $0.5 \mathrm{~g}$ sodium glutamate $\mathrm{l}^{-1}$ and $0.5 \mathrm{~g}$ yeast extract $1^{-1}$ were present as nitrogen sources; and LB (Miller, 1972).

Enzyme assays. $\mathrm{NH}_{4}^{+}$transport activity was determined using the radioactive analogue of $\mathrm{NH}_{4}^{+},\left[{ }^{14} \mathrm{C}\right]$ methylamine $\left(\left[{ }^{14} \mathrm{C}\right] \mathrm{MA}\right)$, in a filter assay (Howitt et al., 1986).

GS activity was measured using the $\gamma$-glutamyltransferase assay described by Fuchs \& Keister (1980), as modified by Howitt \& Gresshoff (1985). Sensitivity to heat was used to distinguish GSII activity from that of GSI: incubation of cell extracts at $50^{\circ} \mathrm{C}$ for $2 \mathrm{~h}$ inactivates GSII, but not GSI activity in strain ANU289 (Howitt \& Gresshoff, 1985).

NR activity was determined with whole cells by following $\mathrm{NO}_{2}^{-}$ production (Nicholas \& Nason, 1957), as described previously (Howitt \& Gresshoff, 1985).

In vitro nitrogenase activity was measured using the acetylene reduction assay (Dilworth, 1966) after derepression of bacterial nitrogenase in solid agar medium inside stoppered test-tubes (Bender $e t$ al., 1986).

The Lowry method was used to determine protein concentration.

Southern blot analysis. Chromosomal DNA was prepared from stationary phase cultures of ANU289 and ANU293 as described by Somerville \& Kahn (1983). Samples of DNA $(5 \mu \mathrm{g})$ were digested with the restriction enzyme EcoRI and electrophoresed through a $0.7 \%$ agarose gel. The DNA in the gel was then nicked by depurination in $0.2 \mathrm{M}-\mathrm{HCl}$ for $10 \mathrm{~min}$ and denatured in $0.5 \mathrm{M}-\mathrm{NaOH}, 1.5 \mathrm{M}-\mathrm{NaCl}$ for $45 \mathrm{~min}$, prior to transfer to a nitrocellulose filter (Sambrook et al., 1989). Plasmids containing $n$ tr $A$ ( $3.2 \mathrm{~kb} E c o R I$ fragment), $n t r B(0.9 \mathrm{~kb}$ EcoRI fragment), ntrC (1.6 kb EcoRI fragment), and $n \operatorname{tr} B-n t r C(0.7 \mathrm{~kb}$ EcoRI fragment) from Bradyrhizobium sp. [Parasponiae] strain RP501 were kindly provided by B. Tracy Nixon (Nixon et al., 1986; and unpublished results from the same group). Probes for the various ntr genes were prepared by digesting plasmids with EcoRI, purifying the appropriate fragments using preparative agarose gels, and labelling 50 $100 \mathrm{ng}$ of the resulting DNA with $\left[\alpha^{32} \mathrm{P}\right] \mathrm{dCTP}$ [3000 Ci mmol-1 (111 TBq $\mathrm{mmol}^{-1}$ ); NEN] using an oligonucleotide-labelling (randomprimer) kit from Pharmacia. Hybridization was performed in $50 \%$ (v/v) formamide, $0.75 \mathrm{M}-\mathrm{NaCl}, 50 \mathrm{~mm}-\mathrm{NaH}_{2} \mathrm{PO}_{4} .2 \mathrm{H}_{2} \mathrm{O}, \mathrm{pH} 7.4$, 5 mM-EDTA, $0.1 \%$ Ficoll (type 400 , Pharmacia), $0.1 \%$ polyvinylpyrrolidone, $0 \cdot 1 \%$ bovine serum albumin (Fraction V), $0.1 \%$ SDS, and
$100 \mu \mathrm{g} \mathrm{ml}^{-1}$ denatured, fragmented salmon sperm DNA at $42{ }^{\circ} \mathrm{C}$ for $20 \mathrm{~h}$. The filter was then washed in $0.1 \times \mathrm{SSC}(15 \mathrm{mM}-\mathrm{NaCl}, 1.5 \mathrm{~mm}$ sodium citrate, $\mathrm{pH} 7$ ) plus $0.1 \% \mathrm{SDS}$ at $65^{\circ} \mathrm{C}$ for $1 \mathrm{~h}$ according to Sambrook et al. (1989). Autoradiography using Kodak X-Omat film was used to visualize hybridization of probes to the filter-bound DNA. Lambda DNA digested with HindIII was used for molecular size markers.

Symbiotic effectiveness test. Siratro (Macroptilium atropurpureum) seeds (12-15 mg) were soaked in concentrated sulphuric acid for $10 \mathrm{~min}$, washed with $70 \%$ ethanol, and soaked in $6 \%$ sodium hypochlorite for $15 \mathrm{~min}$. Seeds were subsequently rinsed with sterile distilled water and germinated on sterile water agar. After $2 \mathrm{~d}$, seedlings were transplanted into sterilized Leonard jars containing Vermiculite and $1 / 2$-strength nitrogen-free nutrient solution (Herridge, 1982) and inoculated with a mid exponential phase culture (approx. $10^{9}$ viable cells per jar). Plants were grown under glasshouse conditions with $16 \mathrm{~h}$ light and $8 \mathrm{~h}$ dark. Leonard jars were refilled with $1 / 2$-strength sterile nutrient solution when necessary. Plants were harvested after 9 weeks and assayed for nitrogenase activity by measuring acetylene reduction (Dilworth, 1966). Plants were sealed inside 1 litre jars containing wet absorbent paper to prevent desiccation and $5 \%$ acetylene was injected. Reactions were carried out at room temperature $\left(25^{\circ} \mathrm{C}\right)$ for $60 \mathrm{~min}$ and the amount of ethylene produced was determined by gas chromatography. Plants were harvested and dried, after which nodules, shoots and roots were weighed. Bacteria were re-isolated from nodules using the method of Rolfe \& Gresshoff (1981).

\section{Results}

\section{Isolation and characterization of the ntrC mutant ANU293}

The insertion mutant ANU293 was isolated while screening for $\mathrm{NH}_{4}^{+}$transport (amt) deficient mutants of strain ANU289. The screen involved plating cells onto BMM plates containing $500 \mathrm{mg}$ kanamycin $1^{-1}$ and $100 \mu \mathrm{M}-\mathrm{NH}_{4} \mathrm{Cl}$ as the sole nitrogen source. Preliminary experiments had established that at this concentration of ammonium, strain ANU289 expresses the Amt system and, therefore, presumably requires the transporter for good growth. Putative amt mutants were selected on the basis of poor growth which was manifest as less dense, more diffuse colonies. From several thousand kanamycin-resistant colonies, 13 putative amt mutants of strain ANU289 were identified. Of these, only ANU293 showed an $\mathrm{Amt}^{-}$phenotype (determined by $\left[{ }^{14} \mathrm{C}\right] \mathrm{MA}$ uptake) when grown to mid-exponential phase under nitrogen-limited conditions (Fig. 1). The rate of MA uptake by ANU293 was similar to that of strain ANU289 bacteroids from siratro nodules, which do not express the Amt system (Howitt et al., 1986), and less than $10 \%$ of the wild-type rate of free-living cells in which the Amt system is expressed (Fig. 1).

Growth rates of the mutant and the wild-type on a variety of nitrogen sources were subsequently compared. The growth kinetics of the mutant and the wild-type 


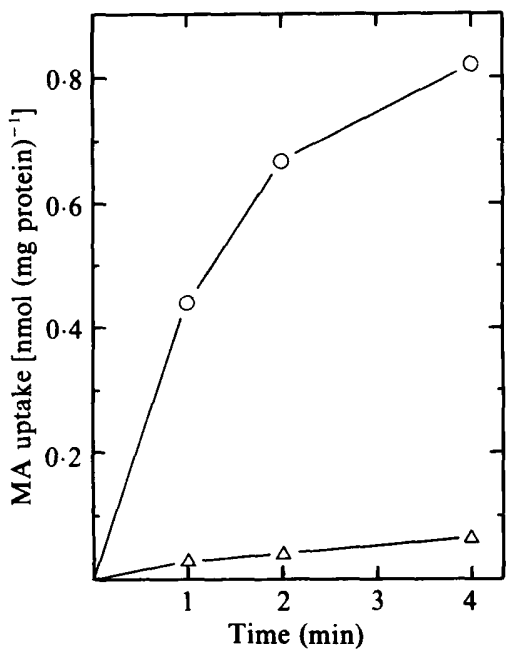

Fig. 1. Time course for $\left[{ }^{14} \mathrm{C}\right] \mathrm{MA}$ uptake by ANU293 $(\triangle)$ and the wildtype, ANU289 (O). Bacteria were grown to mid-exponential phase in N-FGM plus $10 \mathrm{~mm}$-glutamate at $30^{\circ} \mathrm{C}$. Cells were washed twice and resuspended in N-FGM prior to use. Uptake was measured at $30^{\circ} \mathrm{C}$ and $\mathrm{pH} 7.0$ with $10 \mu \mathrm{M}-\left[{ }^{14} \mathrm{C}\right] \mathrm{MA}$ in the external medium. Results are for a typical experiment.

were almost identical when either $20 \mathrm{mM}^{-\mathrm{NH}_{4} \mathrm{Cl}}$ (doubling times of 14 and $13 \mathrm{~h}$, respectively) or $20 \mathrm{~mm}$ glutamine (doubling times of 9 and $8 \mathrm{~h}$, respectively) were used as the sole source of nitrogen. However, the mutant grew more slowly than the wild-type on $20 \mathrm{~mm}$ glutamate ( 25 and $16 \mathrm{~h}$, respectively), and not at all on $20 \mathrm{mM}^{-\mathrm{KNO}_{3}}$ (results not shown).

The complete absence of growth of the mutant on $\mathrm{NO}_{3}^{-}$ suggested that it was affected in the regulation of nitrogen metabolism, rather than only $\mathrm{NH}_{4}^{+}$transport. To test this hypothesis, we investigated the ability of the mutant to induce NR and GSII activities, both of which are under Ntr control in other (brady)rhizobia (Carlson et al., 1987; Martin et al., 1988; Shatters et al., 1989). It had been shown previously that ANU289 is able to induce the expression of NR when transferred from $\mathrm{N}-\mathrm{FGM}$ containing $10 \mathrm{mM}$-glutamate to $\mathrm{N}-\mathrm{FGM}$ with $\mathrm{KNO}_{3}$ as the sole source of nitrogen (Howitt et al., 1988). Fig. 2 shows the results of a similar experiment using both the mutant and wild-type. As expected, NR activity was induced in the wild-type in the presence of $\mathrm{NO}_{3}^{-}$ within $6 \mathrm{~h}$. The mutant, however, was unable to induce NR. This explains the inability of the mutant to grow on $\mathrm{NO}_{3}^{-}$.

Expression of GSII, but not GSI, is also regulated by the nitrogen status of strain ANU289 cells (Howitt \& Gresshoff, 1985). More specifically, GSII is repressed by growth on $10 \mathrm{mM}-\mathrm{NH}_{4} \mathrm{Cl}$ but induced under $\mathrm{N}$ limited conditions, namely $10 \mathrm{~mm}$-glutamate (Howitt \& Gresshoff, 1985). Table 1 shows the results of a similar

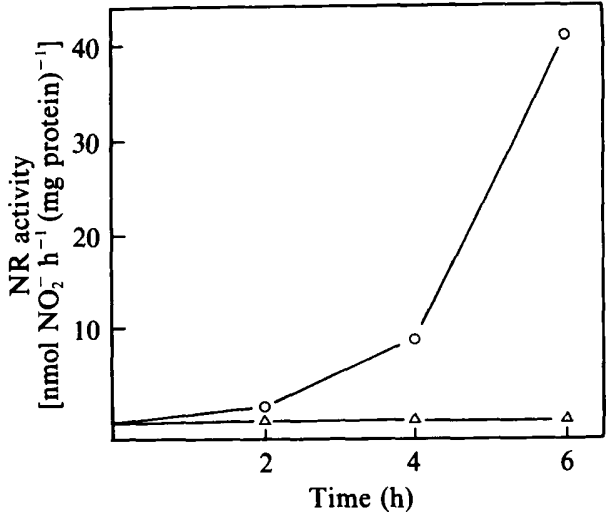

Fig. 2. Induction of NR activity. Wild-type, ANU289 (O) and the mutant, ANU293 $(\Delta)$ were grown to mid-exponential phase in $\mathrm{N}$-FRM plus $10 \mathrm{mM}$-glutamate, then resuspended in N-FGM plus $10 \mathrm{mM}-\mathrm{KNO}_{3}$ at $t=0$. Induction was carried out aerobically at $30^{\circ} \mathrm{C}$. Results are for a typical experiment.

Table 1. Regulation of GS activities in ANU293, and its wild-type parent, ANU289

Cells were grown to mid-exponential phase in N-FGM plus 10 mM-glutamate as sole $\mathrm{N}$-source, then transferred to $\mathrm{N}$-FGM plus $10 \mathrm{mM}-\mathrm{NH}_{4} \mathrm{Cl}$ for $1 \mathrm{~d}$. GS activities were determined prior to and after $\mathrm{NH}_{4} \mathrm{Cl}$ treatment. Results are for a typical experiment.

\begin{tabular}{lllr}
\hline \hline & & \multicolumn{2}{c}{$\begin{array}{c}\text { GS activity } \\
\text { [ } \mu \text { mol } \gamma \text {-glutamylhydroxamate } \\
\text { formed } \text { min }^{-1} \text { (mg protein) }\end{array}$} \\
\cline { 3 - 4 } Strain & $\begin{array}{c}\text { Nitrogen } \\
\text { source }\end{array}$ & GSI & GSII \\
\hline ANU289 & L-Glutamate & $1 \cdot 19$ & 2.92 \\
ANU293 & L-Glutamate & 0.80 & 0.12 \\
ANU289 & $\mathrm{NH}_{4} \mathrm{Cl}$ & 0.87 & 0.04 \\
ANU293 & $\mathrm{NH}_{4} \mathrm{Cl}$ & 0.91 & 0.05 \\
\hline \hline
\end{tabular}

experiment using both the mutant and the wild-type. In contrast to the wild-type, the mutant was unable to induce GSII activity during growth on glutamate. Expression of GSI in the mutant was normal.

Southern blot analysis was used to identify the site of Tn5 insertion in ANU293 (Fig. 3). EcoRI digests of ANU293 and ANU289 chromosomal DNA were probed with Bradyrhizobium sp. [Parasponiae] strain RP501 DNA that contains $n \operatorname{tr} A, n \operatorname{tr} B, n \operatorname{tr} C$ or the $n \operatorname{tr} B-n \operatorname{tr} C$ junction. The mutation in ANU293 was not due to a simple $\mathrm{Tn} 5$ insertion but instead resulted from the cointegration of pSUP1021, the vector used for Tn5 mutagenesis. This was shown using as the hybridization probe ${ }^{32} \mathrm{P}$-labelled pACYC184, the parent plasmid of pSUP1021 that has no homology to Tn5 (Simon et al., 1986). pSUP1021 contains a single EcoRI site and its 


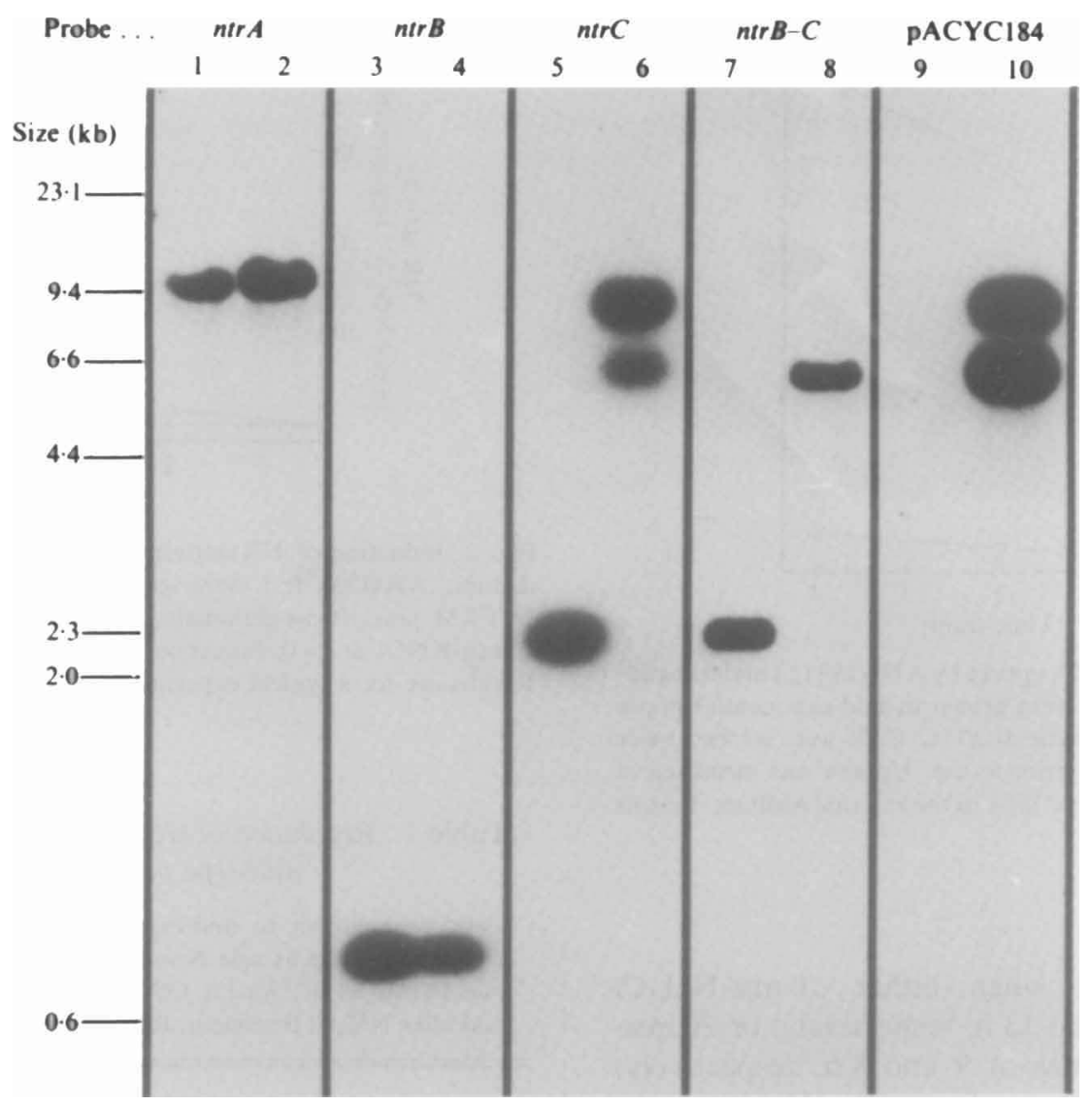

Fig. 3. Southern blot analysis of chromosomal DNA isolated from ANU289 (odd-numbered lanes) and ANU293 (even-numbered lanes). DNA was cut with $E c o R I$, prior to gel electrophoresis, transferred to nitrocellulose filters, and hybridized to probes (see Methods for details). The DNA in each pair of lanes was hybridized to a different probe, as indicated. Plasmid pACYC184, which does not contain TnS, is the parent of pSUP1021, the plasmid used for the mutagenesis of ANU289 (Simon et al., 1986). Pointers indicate the positions of molecular size markers.

integration into the chromosome will split an EcoRI restriction fragment into two fragments that have a total size equal to the sum of the original fragment and the pSUP1021 cointegrate. As shown in Fig. 3, ANU293 contains DNA that hybridizes to pACYC184 (lanes 9 and 10).

There were no differences between ANU293 and ANU289 when the restriction digests were hybridized to the ntr $A$ (lanes 1 and 2) or ntrB (lanes 3 and 4) probes. The $n t r C$ probe hybridized to one restriction fragment in ANU289 but to two restriction fragments in ANU293 that are the same length as those that hybridized to pACYC184 (lanes 5 and 6). This indicates that the site of insertion of pSUP1021 is within the fragment that contains $n t r C$. The shorter of these two new bands $(6.6 \mathrm{~kb})$ also hybridized to the $n \operatorname{tr} B-n \operatorname{tr} C$ junction fragment (lane 8) which shows that this band contains the 5 -end of the ntrC gene. The intensity of labelling of the two bands by the ntrC probe is a function of the position of the insertion - inserts nearer to ntrB would have less DNA in the $6.6 \mathrm{~kb}$ band in common with the ntrC probe (see Fig. 4). In lane 6 (Fig. 3), the $6.6 \mathrm{~kb}$ band is labelled much less than the $9.4 \mathrm{~kb}$ band and this places the site of insertion to the left of the centre of the $n t r C$ probe, well within the $n t r C$ gene. The fact that $0.5 \mathrm{~kb}$ of DNA at the 3 '-end of the ntrC probe is non-coding and, therefore, probably less conserved than the $n t r C$ portion means that the deduced site of insertion would be even further toward the $5^{\prime}$-end of $n t r C$.

\section{Nitrogen fixation by ANU293}

Unlike Rhizobium species, Bradyrhizobium species can be induced to fix nitrogen in vitro. Using the method of Bender et al.(1986) it was found that the mutant was able to reduce acetylene at rates identical to those of wild-type cells (results not shown), indicating that the mutant retained the ability to derepress nitrogenase in vitro. 
Table 2. Symbiotic performance of the ntrC mutant

Siratro seedlings were inoculated with either ANU293 or ANU289 and grown under sterile conditions in a glasshouse. Uninoculated plants were also included as a control. Plants were harvested after 9 weeks of growth. Values are means \pm standard errors at the $95 \%$ confidence interval.

\begin{tabular}{|c|c|c|c|c|c|c|c|}
\hline \multirow[b]{2}{*}{ Inoculum } & \multirow[b]{2}{*}{$\begin{array}{l}\text { No. of } \\
\text { plants }\end{array}$} & \multirow{2}{*}{$\begin{array}{c}\text { Nodule } \\
\text { fresh } \\
\text { weight } \\
\text { (mg per plant) }\end{array}$} & \multicolumn{3}{|c|}{ Dry weight of plant part (mg per plant) } & \multicolumn{2}{|c|}{$\begin{array}{l}\text { Nitrogenase activity } \\
\mathrm{mmol} \mathrm{C}_{2} \mathrm{H}_{4} \text { formed h }\end{array}$} \\
\hline & & & Nodules & Shoot & Root & $\begin{array}{c}\text { (g nodule } \\
\text { fresh weight) }\end{array}$ & $\underset{\text { weight })^{-1}}{(\mathrm{~g} \text { dry }}$ \\
\hline $\begin{array}{l}\text { ANU289 } \\
\text { ANU293 } \\
\text { None }\end{array}$ & $\begin{array}{l}23 \\
26 \\
34\end{array}$ & $\begin{array}{c}121 \pm 34 \\
46 \pm 20 \\
0\end{array}$ & $\begin{array}{c}16 \pm 2 \\
7 \pm 1 \\
0\end{array}$ & $\begin{array}{c}121 \pm 13 \\
48 \pm 2 \\
17 \pm 1\end{array}$ & $\begin{array}{l}48 \pm 6 \\
24 \pm 2 \\
25 \pm 1\end{array}$ & $\begin{array}{c}12 \pm 3 \\
10 \pm 3 \\
0\end{array}$ & $\begin{array}{c}74 \pm 10 \\
62 \pm 20 \\
0\end{array}$ \\
\hline
\end{tabular}

\section{Symbiotic phenotype of ANU293}

To test the symbiotic effectiveness of ANU293, siratro seedlings were inoculated with either mutant or wildtype strains and grown under sterile conditions. Uninoculated plants were included as a control. After 9 weeks, both sets of inoculated plants appeared healthy and had dark green leaves. In contrast, plants without inoculum were stunted and chlorotic with pale, yellow leaves. Bacteria re-isolated from nodules induced by the mutant retained kanamycin resistance and showed the same growth characteristics as ANU293. Plants were harvested and nitrogenase activity of intact plants measured using acetylene reduction. Nodule fresh weights and nodule, shoot and root dry weights were also determined (Table 2). Specific nitrogenase activity of nodules induced by the mutant ANU293 was not significantly different from that of nodules induced by the wild-type. However, nodule, root and shoot dry weights of plants inoculated with ANU293 were significantly lower than control plants inoculated with ANU289, although they were higher than those of uninoculated plants (Table 2). The ability of mutant ANU293 to induce nodules on siratro roots was subsequently tested using the method of Mathews et al. (1989). There was no significant difference between the mutant and the wild-type in their ability to initiate nodules on siratro (results not shown). This suggests that the reduced growth of plants inoculated with the mutant was a result of retarded nodule development rather than decreased or delayed nodule initiation.

\section{Discussion}

The results presented above indicate that ANU293 is an $n t r C$ mutant of ANU289. The pleiotropic effects of this mutation on the expression of several genes involved in nitrogen metabolism, namely those encoding Amt, NR and GSII, are consistent with this conclusion.

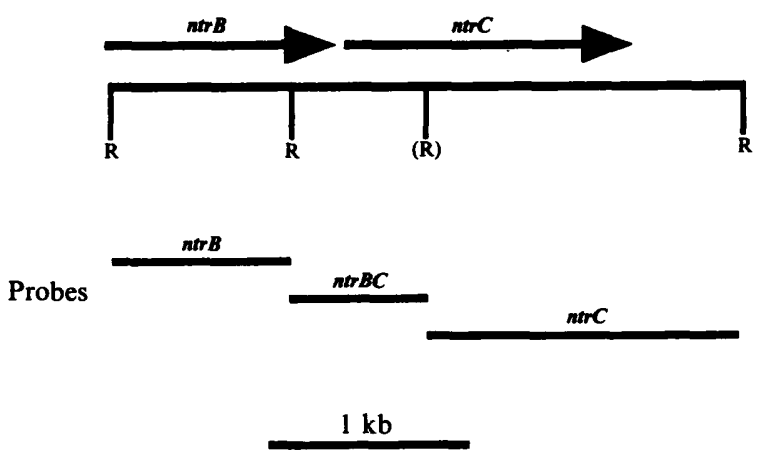

Fig. 4. Physical map of the ntrB-ntrC region of Bradyrhizobium (Parasponia) sp. ANU289 based on the results of Fig. 3 and a comparison with published results of Nixon et al. (1986). EcoRI restriction sites are marked with the letter $R$. Also shown are the Bradyrhizobium sp. [Parasponiae] strain RP501 EcoRI fragments that were used as probes for the Southern blot analysis shown in Fig. 3. The EcoRI site shown in parentheses is present in strain RP501 but apparently not in strain ANU289.

The results of the Southern blot analysis shown in Fig. 3 suggest that $n t r B$ and $n t r C$ are adjacent in ANU289. Furthermore, the position of EcoRI sites in and around $n t r B-n t r C$ in ANU289 are similar to those in Bradyrhizobium sp. [Parasponiae] strain RP501 (Nixon et al., 1986), except for the absence of the one $E c o$ RI site within $n t r C$ (see Fig. 4). It seems likely that $n t r B$ and $n t r C$ are part of a single operon, as they are in Bradyrhizobium sp. [Parasponiae] strain RP501 (Nixon et al., 1986). In contrast, $n$ tr $A$ appears to be unlinked to $n \operatorname{tr} B$ and $n t r C$.

Transcription of genes under Ntr control in bacteria requires NtrA, a unique sigma factor which combines with the RNA polymerase core enzyme, and the regulatory protein NtrC (or NR1; Hirschman et al., 1985; Hunt \& Magasanik, 1985; Merrick \& Gibbons, 1985). NtrC has sequence-specific DNA-binding activity (Ames \& Nikaido, 1985) which has been implicated in transcriptional activation (Reitzer \& Magasanik, 1986). Expression of the ntrC gene occurs 
when cells are grown in N-limited media (Magasanik, 1982). The phenotype of ANU293 is similar to those of other (brady)rhizobial ntrC mutants. For example, Bradyrhizobium japonicum ntrC mutants are unable to utilize $\mathrm{KNO}_{3}$ as the sole nitrogen source, nor are they able to transcribe the $g \ln I I$ gene (encoding GSII) in aerobic, nitrogen-starved cultures. Expression of $g \ln A$ (encoding GSI), on the other hand, is not affected by the lesion in ntrC (Martin et al., 1988). Rhizobium meliloti and Azorhizobium caulinodans ntrC mutants, like ANU293, are able to form effective nodules on their host plants, although $A$. caulinodans $n t r C$ mutants exhibit delayed nodulation and reduced nitrogen fixation activity (Szeto et al., 1987; Pawlowski et al. 1987).

In enteric bacteria, the Ntr system controls the utilization of urea, histidine, proline and arginine (Magasanik , 1982). In contrast, results with Bradyrhizobium and Rhizobium species suggest that utilization of histidine, proline and arginine is not dependent on the Ntr system in these genera (Ronson et al., 1987; Martin et al., 1988). Nonetheless, Szeto et al. (1987) found that while $n t r C$ is not absolutely required for growth of $R$. meliloti on a variety of amino acids, $n t r C$ mutants do suffer a growth disadvantage when arginine or proline is the sole nitrogen source. A. caulinodans ntrC mutants, on the other hand, grow more slowly than the wild-type when arginine or histidine, but not proline, is provided as the primary N-source (Pawlowski et al., 1987). ANU293 grew more slowly than the wild-type on arginine and glutamate but showed normal growth rates on urea, proline and histidine (results not shown). The reduced growth rates of ANU293 on glutamate and arginine may be a consequence of the $\mathrm{Amt}^{-}$phenotype, as was found for an $\mathrm{Amt}^{-}$mutant of Klebsiella pneumoniae (Castorph \& Kleiner, 1984).

The ability of the $n t r C$ mutant ANU293 to fix nitrogen at normal rates, both in vitro and in planta, suggests that transcription of nif genes is not dependent on NtrC in strain ANU289. A similar conclusion was drawn for $R$. meliloti, at least for nif regulation in planta (Szeto et al., 1987). However, the ex planta transcription of several $R$. meliloti nif genes does require $\mathrm{NtrC}$. The situation appears to be different again in $A$. caulinodans where $\mathrm{NtrC}$ exerts a profound effect on the induction of nif gene transcription both ex planta and in planta (Pawlowski et al., 1987).

Although the mutant was able to infect siratro efficiently and form effective nodules, plant growth was slower, suggesting that nodule development was delayed. Prior to the onset of nitrogen fixation, rhizobia require a net input of reduced nitrogen for growth and replication. Nitrogen compounds supplied by the plant may include ammonia and amino acids derived from seed reserves. Since the mutant grows poorly on some amino acids and is unable to scavenge $\mathrm{NH}_{4}^{+}$because of its $\mathrm{Amt}^{-}$ phenotype, under the conditions likely to prevail in the developing nodule the mutant may exhibit slower growth rates than the wild-type. This could delay bacteroid development and the onset of nitrogen fixation, which in turn would manifest itself in a reduced rate of plant growth relative to wild-type inoculated plants.

\section{Conclusion}

We have isolated a ntrC mutant of Bradyrhizobium (Parasponia) sp. ANU289, and designated it ANU293. The phenotype of ANU293 indicates that expression of Amt, NR and GSII, but not nitrogenase or GSI, are dependent on the transcriptional activator $\mathrm{NtrC}$ in ANU289.

We thank Joanne Perks for typing the manuscript and Dr Susan Howitt for providing the Tn5 bank of ANU289. We also thank Dr Howitt and Dr Michael Kahn for their advice in analysing the mutant. This project was funded by a grant from the Australian Research Council (D.A.D.) and a Commonwealth Postgraduate Award (M.K.U.)

\section{References}

Ames, G. F.-L. \& NikaIDo, K. (1985). Nitrogen regulation in Salmonella typhimurium. Identification of an ntrC protein-binding site and definition of a consensus binding sequence. EMBO Journal 4, 539-547.

Ausubel, F. M. (1984). Regulation of nitrogen fixation genes. Cell 37, $5-6$.

Ausubel, F. M., Buikema, W. J., Earl, C. D., Klingensmith, B. T., NiXON, B. T. \& SzETo, W. W. (1985). Organization and regulation of Rhizobium meliloti and Parasponia Bradyrhizobium nitrogen fixation genes. In Nitrogen Fixation Research Progress, pp. 167-179. Edited by H. J. Evans, P. J. Bottomley \& W. E. Newton. Dordrecht, The Netherlands: Martinus Nijhoff.

Bender, G. L., Plazinski, J. \& Rolfe, B. G. (1986). Asymbiotic acetylene reduction by a fast-growing cowpea Rhizobium strain with nitrogenase structural genes located on a symbiotic plasmid. Applied and Environmental Microbiology 51, 868-871.

BERGERSEN, F. J. (1969). The growth of Rhizobium in synthetic media. Australian Journal of Biological Science 14, 349-360.

Carlson, T. A., Martin, G. B. \& Chelm, B. K. (1987). Differential transcription of the two glutamine synthetase genes of Bradyrhizobium japonicum. Journal of Bacteriology 169, 5861-5866.

CASTORPH, H. \& KLEINER, D. (1984). Some properties of a Klebsiella pneumoniae ammonium transport negative mutant $\left(\mathrm{Amt}^{-}\right)$. Archives of Microbiology 139, 245-247.

DILWORTH, M. J. (1966). Acetylene reduction by nitrogen fixing preparations from Clostridium pasteurianum. Biochimica et Biophysica Acta 127, 285-294.

FUCHS, R. L. \& KeISTER, D. L. (1980). Identification of two glutamine synthetases in Agrobacterium. Journal of Bacteriology 141, 996-998.

Gussin, G. N., Ronson, G. W. \& Ausubel, F. M. (1986). Regulation of nitrogen fixation genes. Annual Review of Genetics 20, 267-291.

HERRIDGE, D. F. (1982). Use of the ureide technique to describe the nitrogen economy of field grown soybeans. Plant Physiology 70, 7-11.

Hirschman, J., Wong, P. K., Sei, K., Keener, J. \& Kustu, S. (1985). Products of nitrogen regulatory genes ntrA and ntrC of enteric bacteria activate $g \ln A$ transcription in vitro: evidence that the $n t r A$ product is a sigma factor. Proceedings of the National Academy of Sciences of the United States of America 82, 7525-7529. 
HowIrT, S. M. \& GResshofF, P. M. (1985). Ammonia regulation of glutamine synthetase in Rhizobium sp. ANU289. Journal of General Microbiology 131, 1433-1440.

Howitt, S. M., Udvardi, M. K., Day, D. A. \& Gresshoff, P. M. (1986). Ammonia transport in free-living and symbiotic Rhizobium sp. ANU289. Journal of General Microbiology 132, 257-261.

HowItT, S. M., DAY, D. A., SCOTT, K. F. \& Gresshoff, P. M. (1988). Mutants of Bradyrhizobium (Parasponia) sp. ANU289 affected in assimilatory nitrate reduction also show lowered symbiotic effectiveness. Journal of Plant Physiology 132, 5-9.

HUNT, T. P. \& MAGaSANIK, B. (1985). Transcription of $g \ln A$ by purified Escherichia coli components : core RNA polymerase and the products of $g \ln F, g \ln G$ and $g \ln L$. Proceedings of the National Academy of Sciences of the United States of America 82, 8453-8457.

Jayakumar, A., Schulman, I., MacNeil, D. \& Barnes, E. M., JR (1986). Role of Escherichia coli glnALG operon in regulation of ammonium transport. Journal of Bacteriology 166, 281-284.

MAGASANIK, B. (1982). Genetic control of nitrogen assimilation in bacteria. Annual Reviews of Genetics 16, 135-168.

Martin, G. B., Chapman, K. A. \& Chelm, B. K. (1988). Role of the Bradyrhizobium japonicum ntrC gene product in differential regulation of the glutamine synthetase II gene $(g \ln I)$. Journal of Bacteriology 170, 5452-5459.

Mathews, A., Carroll, B. J. \& Gresshoff, P. M. (1989). Development of Bradyrhizobium infections in a supernodulating and non-nodulating mutants of soybean (Glycine max [L.] Merrill). Protoplasma 150, 40-47.

MERRICK, M. J. \& GibBINS, J. R. (1985). The nucleotide sequence of the nitrogen-regulation gene ntrA of Klebsiella pneumoniae and comparison with conserved features in bacterial RNA polymerase sigma factors. Nucleic Acids Research 13, 7607-7619.

MilleR, J. H. (1972). Experiments in Molecular Genetics. Cold Spring Harbor, NY: Cold Spring Harbor Laboratory.

Nicholas, D. J. D. \& NASON, A. (1957). Determination of nitrate and nitrite. Methods in Enzymology 3, 983-984.

Nixon, B. T., Ronson, C. W. \& Ausubel, F. M. (1986). Twocomponent regulatory systems responsive to environmental stimuli share strongly conserved domains with the nitrogen assimilation regulatory genes $n t r B$ and $n t r C$. Proceedings of the National Academy of Sciences of the United States of America 83, 7850-7854.

Pawlowski, K., Ratet, P., Schell, J. \& de Bruijn, F. J. (1987). Cloning and characterization of nifA and ntrC genes of the stem nodulating bacterium ORS571, the nitrogen fixing symbiont of Sesbania rostrata: regulation of nitrogen fixation (nif) genes in the free living versus symbiotic state. Molecular and General Genetics 206, 207-219.

Reitzer, L. J. \& Magasanik, B. (1986). Transcription of $g \ln A$ in Escherichia coli is stimulated by activator bound to sites far from the promoter. Cell 45, 785-792.

Rolfe, B. G. \& Gresshoff, P. M. (1981). Rhizobium mutant interaction during the establishment of nodulation in white clover. Australian Journal of Biological Sciences 33, 491-504.

Ronson, C. W., Nixon, B. T., Albright, L. M. \& Ausubel, F. M. (1987). Rhizobium meliloti ntrA (rpoN) gene is required for diverse metabolic functions. Journal of Bacteriology 169, 2424-2431.

Rossbach, S., SCHELl, J. \& DE BRUIJ,, F. J. (1987). The ntrC gene of Agrobacterium tumefaciens C58 controls glutamine synthetase (GSII) activity, growth on nitrate and chromosomal but not Ti-encoded arginine catabolism pathways. Molecular and General Genetics 209, 419-426.

SAMbroOK, J., Fritsch, E. F. \& MaNiatis, T. (1989). Molecular Cloning. A Laboratory Manual. Cold Spring Harbor, NY: Cold Spring Harbor Laboratory.

Servin-Gonzalez, L. \& BastarRachea, F. (1984). Nitrogen regulation of synthesis of the high affinity methylammonium transport system of Escherichia coli. Journal of General Microbiology 130, 3071-3077.

Shatters, R. G., Sommerville, J. E. \& KahN, M. L. (1989). Regulation of glutamine synthetase II activity in Rhizobium meliloti 104A14. Journal of Bacteriology 171, 5087-5094.

Simon, R., O'Connell, M., Labes, M. \& Puhler, A. (1986). Plasmid vectors for the genetic analysis and manipulation of rhizobia and other Gram-negative bacteria. Methods in Enzymology 118, 640-659.

Somerville, J. E. \& KaHN, M. K. (1983). Cloning of the glutamine synthetase I gene from Rhizobium meliloti. Journal of Bacteriology 156, 168-176.

Stanley, J., Van Slooten, J., Dowling, D. N., Finan, T. \& Broughton, W. J. (1989). Molecular cloning of the ntrA gene of the broad host-range Rhizobium sp. NGR234, and phenotypes of a sitedirected mutant. Molecular and General Genetics 217, 528-532.

Szeto, W. W., Nixon, B. T., Ronson, C. W. \& Ausubel, F. M. (1987). Identification and characterization of the Rhizobium meliloti ntrC gene: $R$. melilot $i$ has separate regulatory pathways for activation of nitrogen fixation genes in free-living and symbiotic cells. Journal of Bacteriology 169, 1423-1432.

Trinick, M. J. \& Galbraith, J. (1980). The Rhizobium requirement of the non-legume Parasponia in relationship to the cross-inoculation group concept of legumes. New Phytologist 86, 17-26. 